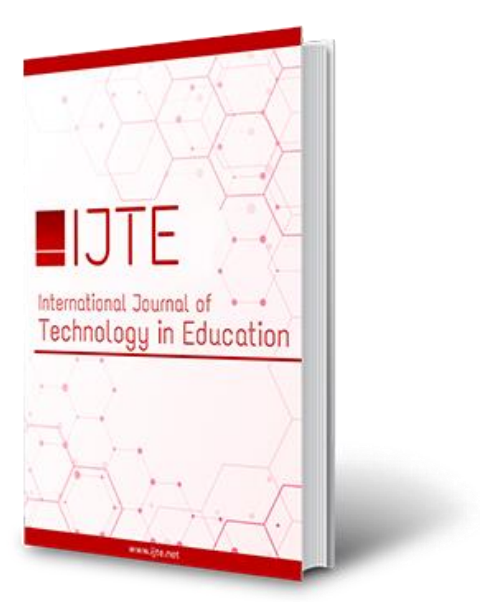

\title{
A History of Instructional Media, Instructional Design, and Theories
}

\author{
Yunjo An \\ University of North Texas, United States
}

www.ijte.net

\section{To cite this article:}

An, Y. (2021). A history of instructional media, instructional design, and theories. International Journal of Technology in Education (IJTE), 4(1), 1-21. https://doi.org/10.46328/ijte.35

\begin{abstract}
The International Journal of Technology in Education (IJTE) is a peer-reviewed scholarly online journal. This article may be used for research, teaching, and private study purposes. Authors alone are responsible for the contents of their articles. The journal owns the copyright of the articles. The publisher shall not be liable for any loss, actions, claims, proceedings, demand, or costs or damages whatsoever or howsoever caused arising directly or indirectly in connection with or arising out of the use of the research material. All authors are requested to disclose any actual or potential conflict of interest including any financial, personal or other relationships with other people or organizations regarding the submitted work.
\end{abstract}




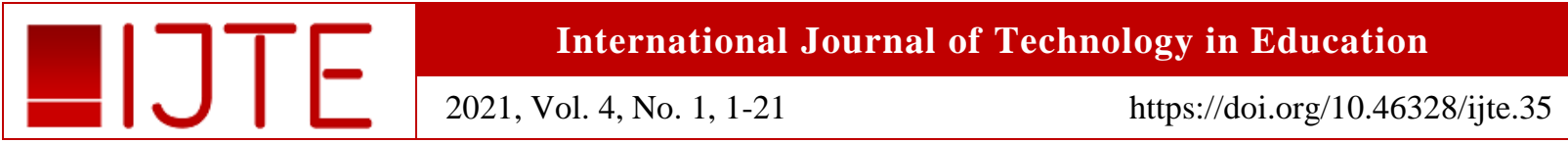

\title{
A History of Instructional Media, Instructional Design, and Theories
}

\author{
Yunjo An
}

\begin{tabular}{|c|c|}
\hline Article Info & Abstract \\
\hline Article History & This paper discusses the history of the instructional design and technology field \\
\hline Received: & in four major time periods: (1) $1900 \mathrm{~s}-1930 \mathrm{~s}$, (2) World War II $-1970 \mathrm{~s}$, (3) \\
\hline 9 March 2020 & 1980s - 1990s, and (4) 21 st century. Since the 20th century has been discussed in \\
\hline Accepted: & detail in earlier works, this paper puts more focus on the 21 st century section, \\
\hline $2 J$ & which includes discussions of social media, online and blended learning, mobile \\
\hline & learning, the open educational resource (OER) movement, massive open online \\
\hline & courses (MOOCs), virtual reality (VR) and augmented reality (AR), digital \\
\hline Keywords & game-based learning (DGBL), gamification, the maker movement, new \\
\hline History & instructional design process models, and instructional-design theory. While \\
\hline $\begin{array}{l}\text { Instructional media } \\
\text { Instructional design }\end{array}$ & previous discussions of the history of the field focused on the history of \\
\hline Learning theories & instructional media and instructional design and the evolution of learning \\
\hline Instructional-design theories & $\begin{array}{l}\text { theories, this paper includes the discussion of the evolution of instructional- } \\
\text { design theories and models, which have received relatively less attention. }\end{array}$ \\
\hline
\end{tabular}

\section{Introduction}

Learning history allows us to better understand our current state and provides insights into the future. In order to better understand the current trends and issues in the instructional design and technology field and make informed predictions about its future, it is critical to understand how the field has evolved. Many scholars have discussed the history of instructional design and technology (e.g., Molenda, 2008; Reiser, 2001a, 2001b, 2018; Saettler, 1968, 1990) focusing mainly on the history of the field in the 20th century. In this paper, the history of the field is discussed in four major time periods: (1) 1900s - 1930s, (2) World War II - 1970s, (3) 1980s 1990s, and (4) 21 st century. Since the 20th century has been discussed in detail in earlier works, this paper puts more focus on the 21 st century section. While previous discussions of the history of instructional design and technology focused on the history of instructional media and instructional design and the evolution of learning theories, this paper includes the discussion of the evolution of instructional-design theories and models, which have received relatively less attention. It should be noted that this paper focuses on major events in the United States.

\section{0s-1930s}

\section{The Visual Instruction Movement}

In the early part of the twentieth century when school museums, the equivalent of district-wide media center, 
came to existence, most of the media housed in school museums were visual media, such as photographs, slides, and films. The increasing interest in using visual media in education was referred to as the visual instruction movement (Reiser, 2018; Saettler, 1990). In 1913, Thomas Edison envisioned that school systems would be completely changed with visual media in the next ten years, proclaiming: "Books will soon be obsolete in the schools... It is possible to teach every branch of human knowledge with the motion picture" (cited in Saettler, 1968, p. 98).

Although the revolutionary changes in school systems envisioned by Edison did not happen, the visual instruction movement did grow, resulting in five national professional organizations for visual instruction and a number of courses and textbooks on visual instruction. Despite the growth of the visual instruction movement, teachers and textbooks were still viewed as the primary means of instruction, while the visual materials housed in school museums were viewed as supplementary materials (Reiser, 2018; Saettler, 1990). According to Cuban (1986), the impact of the visual instruction was limited due to a variety of factors, including poor instructional quality of relevant films in many subject areas, the costs associated with purchasing and maintaining films and equipment, the difficulty teachers had in using film equipment, and teacher resistance to change.

\section{The Audiovisual Instruction Movement}

As media began incorporating sound in the 1920s, the visual instruction movement was expanded to the audiovisual instruction movement (Finn, 1972; McCluskey, 1981). Radio gained a great deal of attention, but it had very little impact on instructional practices due to various factors including poor equipment, poor reception of radio signals, and teacher resistance to change (Cuban, 1986; Reiser, 2018). The audiovisual instruction movement continued to evolve despite the adverse economic effects of the Great Depression, which began in 1929. The Department of Visual Instruction (DVI), which was part of the National Education Association at that time and is now called as Association for Educational Communication and Technology (AECT), was formed in 1932 (Saettler, 1990).

\section{Behaviorism}

Before World War II, learners were only expected to understand and learn rudimentary skills, such as reading, writing, and arithmetic. During this time period, behaviorism dominated the psychology of learning, and behaviorist theories were used as the basis for designing many of the early audiovisual materials (Edgar, 2012; Ertmer \& Newby, 2013). Behaviorism grew with the work by Pavlov, Watson, Thorndike, and Skinner.

Thorndike (1905) formalized the Law of Effect. Watson (1913) published the article "Psychology as the Behaviorist Views It," which is often called "The Behaviorist Manifesto," and claimed that psychology is the science of human behavior, which should be studied under laboratory conditions. B. F. Skinner (1938) believed that classical conditioning was too simplistic to be used to describe complex human behavior and formulated the operant conditioning learning theory. 


\section{World War II - 1970s \\ Word War II and Instructional Media}

The growth of the audiovisual instruction movement slowed in schools during World War II (WWII), but a wide variety of audiovisual materials and equipment, such as training films, film projectors, and overhead projectors, were extensively used to train U.S. military personnel and to prepare U.S. civilians to work in industry (Reiser, 2018; Saettler, 1990). During the 1950s, there was an enormous growth in the use of instructional television, but many of the instructional television projects did not last long. The interest in using television for instructional purposes subsided by the mid-1960s (Reiser, 2018). The term multimedia was coined in the 1950s to describe early combinations of various media used to enhance teaching and learning (Heinich, Molenda, Russell, \& Smaldino, 1999).

\section{The Behavioral Objectives Movement}

The behavioral objectives movement emphasized that learning objectives should be written in observable and measurable terms. In the 1950s, the Taxonomy of Educational Objectives written by Benjamin Bloom and his colleagues gave another boost to the behavioral objectives movement (Bloom, Engelhart, Furst, Hill, \& Krathwohl, 1956). In the early 1960s, Robert Mager (1962) published Preparing Objectives for Programmed Instruction, which described how to write objectives that include learner behaviors, conditions, and standards. The behavioral objectives are still prevalent and advocated by many instructional designers and educators.

\section{Teaching Machines, Programmed Instruction, and Computer-Assisted Instruction}

Along with behavioral objectives, teaching machines, programmed instruction, and computer-assisted instruction (CAI) were among the major works influenced by behaviorism (Saettler, 1990). Teaching machines, which were advocated by Skinner (1958), used reinforcement to increase learning. Programmed instruction, which was also advocated by Skinner, ran from the mid-1950s through the mid-1960s. Skinner (1958) stated that programmed instruction should include behavioral objectives, present content in small steps, require active learner response to frequent questions, allow for self-pacing, and provide immediate feedback.

Many of the programmed instructional materials developed during the late 1950s through the 1960s were tested and evaluated while they were being developed. In 1967, Michael Scriven (1967) coined the term formative evaluation and contrasted it with summative evaluation. During the 1960s and early 1970s, CAI systems such as PLATO and TICCIT, were developed even though much of the early work in CAI was done in the 1950s by researchers at IBM (Lewis \& Pask, 1965; Stolorow \& Davis, 1965). However, CAI had had very little impact on education by the end of the 1970s (Pagliaro, 1983).

\section{Launch of Sputnik and Shift from Behaviorism to Cognitivism}

In 1957, when the Soviet Union launched Sputnik, the first artificial Earth satellite, the space race began. 
Realizing that American schools were falling behind, the United States poured millions of dollars into improving math and science education. The training needs of WWII and the launch of Sputnik evoked reflection on educational systems and new questions for learning. There was an apparent need to educate people to think critically, learn complex skills, and solve problems. Behavioral principles could not adequately address the acquisition of higher-level skills, and a new learning theory was needed (Edgar, 2012).

Cognitivism emerged in the 1950s and surfaced as a dominant learning theory in the late 1970s (Edgar, 2012; Ertmer \& Newby, 2013; Reiser, 2018). Psychologists and educators began to focus more on complex cognitive processes such as reasoning, information procession, and problem solving and de-emphasize overt and observable behavior (Snelbecker, 1983). For example, Piaget's theory of cognitive development proposed four stages of cognitive development, namely sensorimotor, preoperational, concrete operational, and formal operational stage (McLeod, 2018; Woolfolk, 2010).

\section{Instructional Design (ID)}

The origin of ID. The origin of the ID process can be traced back to WWII (Dick, 1987). During WWII, a large number of psychologists and educators, including Robert Gagné, Leslie Briggs, and John Flanagan, were called upon to develop training materials for the military services and conduct research. Many of the psychologists continued to work on solving instructional problems after the war, and they started developing a number of innovative analysis, design, and evaluation procedures during the late 1940s and throughout the 1950s (Dick, 1987; Saettler, 1990). For example, Robert Miller (1962) developed a detailed task analysis method during this period.

In 1962, Robert Glaser introduced the concept of instructional design (Glaser, 1962). In 1965, Robert Gagné (1965) published the first edition of The Conditions of Learning, in which he identified five major categories of learning: verbal information, intellectual skills, cognitive strategies, motor skills, and attitudes. In the book, Gagné also described nine events of instruction (Gagné, 1965, 1985). His description of the five learning outcomes and the events of instruction became the foundation of ID practices (Reiser, 2018).

The systems approach to ID. During the 1970s, a number of scholars created new ID models for systematically designing instruction (e.g., Dick \& Carey, 1978; Gagne \& Briggs, 1974; Gerlach \& Ely, 1971; Kemp, 1971). Some of the models developed during the period, such as the Dick and Carey model, became standards in the field and have been frequently taught to graduate students studying ID programs (Johnson, Xin, Mackal, \& Reiser, 2012). In addition to ID models, many graduate programs in ID were created during the 1970s (Redfield \& Dick, 1984).

\section{Theory of Instruction}

Little attention was paid to instructional-design theory since most of the attention in the field of instructional design was on the ID process or ID models (Reigeluth, 1983). However, the advances of instructional media and 
learning theories contributed to the development of the instructional design theories and models. Gagné, Skinner, Bruner, Ausubel, Merrill, and Reigeluth were among the major contributors. Bruner, who developed a model of instruction based on discovery methods, was among the first to talk about developing a "theory of instruction" (Bruner, 1966).

Reigeluth and Merrill $(1978,1979)$ proposed that there were three major components of a theory of instruction, which included instructional methods, instructional conditions, and instructional outcomes. Further, Reigeluth and Merrill (1979) extended the conditions-methods-outcomes framework in an attempt to identify all of the important kinds of method variables that should be included in a comprehensive model or a theory of instruction. The extended framework included three types of instructional methods: organizational, delivery, and management.

\section{0s - 1990s}

\section{Personal Computers, Hypermedia, and Internet}

The interest in using computers for instructional purposes increased in the 1980s, even though computers were used in education much earlier (Reiser, 2018). The Center for Social Organization of Schools (1983) reported that computers were being used in over 40 percent of elementary schools and over 75 percent of all secondary schools in the United States by January 1983. Although schools had one computer for every nine students on average by 1995 , the impact of computers on instructional practices were minimal. Computers were mainly used for drill and practice or for teaching computer skills (e.g., word processing). Many teachers reported little or no use of computers for instructional purposes (Becker, 1998; Office of Technology Assessment, 1995; Reiser, 2018).

In the 1980s, the computer began to combine some of the distinct media, such as textbooks, audio, visuals, and motion media (Heinich, Molenda, Russell, \& Smaldino, 1999). Hypermedia systems, such as HyperCard, were widely used in schools. Hypermedia refers to "computer software that uses elements of text, graphics, video, and audio connected in such a way that the user can easily move within the information" (Heinich, Molenda, Russell, \& Smaldino, 1999, p. 230). Based on cognitive theories, hypermedia was designed to resemble the way people organize information with concepts and their relationships. In the 1990s, research on the use of hypermedia for learning was active (e.g., Dillan \& Gabbard, 1998; Weller, Repman, Lan, \& Rooze, 1995). It is worth noting that the terms hypermedia, multimedia, and interactive video were often used interchangeably in the literature (Liao, 1999).

The World Wide Web became publicly available in 1991. According to the National Center for Education Statistics, 65 percent of all public schools had access to the Internet in the fall of 1996, and dial-up Internet connections were used by about 74 percent of public schools having Internet access in 1996 (Heaviside, Riggins, \& Farris, 1997). The Internet changed the ways of teaching and learning by providing learners with immediate access to information. 


\section{Distance Education/Online Education}

Although distance education was common in the late 1800s in the form of correspondence education, its rapid growth began in the late 1990s with the advance of online technologies. Shortly after the World Wide Web was unveiled in 1991, universities and colleges began experimenting with online courses (Kentnor, 2015). In 1998, nonprofit institutions sought to increase revenues by entering into the online marketplace. For example, New York University (NYU) created NYU Online in 1998. NYU was the first large nonprofit university to create a for-profit online education subsidiary (Arenson, 1998a). Western Governors University, a nonprofit online university, was founded in the same year in order to make education more accessible. The California Virtual University opened in November of 1998 (Arenson, 1998b). Since its inception in the 1700s, distance education has made education more accessible and attainable for those who are unable to sit in traditional classrooms.

\section{The Clark-Kozma Debate}

Most research on instructional media from the 1920s through the 1960s focused on media comparisons. In the 1980s, Richard Clark and Robert Kozma started the famous media debate. After reviewing the results of studies and meta-analyses of research comparing the effectiveness of various media, Clark (1983) claimed that "media are mere vehicles that deliver instruction but do not influence student achievement any more than the truck that delivers our groceries causes changes in our nutrition" (p. 445). Kozma (1994) argued that "...Clark's separation of media from method creates an unnecessary and undesirable schism between the two. Medium and method should have a more integral relationship" (p.16). He suggested moving from "Do media influence learning?" to "In what ways can we use the capabilities of media to influence learning for particular students, tasks, and situations?" The debate between Clark and Kozma has instigated much discussion and debate on whether or not media influences learning.

\section{Instructional Design (ID) and Human Performance Improvement}

Interest in the ID process continued to grow during the 1980s and remained strong especially in business, industry, and the military. However, ID had minimal impact on instructional practices in K-12 schools and in higher education (Reiser, 2018). In 1986, the International Board of Standards for Training, Performance, and Instruction (ibstpi) published the first set of instructional design competencies. The ibstpi revised the ID competences in the year 2000 and more recently in 2012, in response to changing learning environments and new expectations for instructional designers (Koszalka, Russ-Eft, \& Reiser, 2013).

In the 1990s, instructional designers began to take an interest in using computers as tools to improve on-the-job performance as well as to enhance learning. The human performance improvement movement broadened the scope of the ID field and led instructional designers to consider and identify non-instructional interventions (Reiser, 2018). During this decade, an interest in using electronic performance support systems (EPSS) and knowledge management systems to support learning and on-the-job performance began to flourish (Gery, 1991; Schwen, Kalman, Hara, \& Kisling, 1998). 


\section{Constructivism and Constructionism}

In the 1980s and 1990s, the growing interest in constructivist views of teaching and learning was another major trend in the instructional design field. Constructivists viewed learning as an active process of constructing rather than acquiring knowledge. Therefore, instruction was viewed as a process to support the construction rather than communication of knowledge (Duffy \& Cunningham, 1996). Many scholarly works focused on topics related to constructivist learning including cognitive apprenticeship (Collins, Brown, \&Newman, 1989), problem-based learning (Savery \& Duffy, 1995), problem solving (Jonassen, 1997), cognitive load during problem solving (Sweller, 1988), learning by doing (Schank, 1994), teaching complex cognitive skills (van Merriënboer, 1997), and designing constructivist learning environments (Jonassen, 1999).

In the1980s, Papert (1993a, b) developed constructionism, which suggested that learning is most effective when students are actively engaged in the construction of concrete and meaningful artifacts. In his books, Mindstorms and The Children's Machine, Papert suggested that the computer should be an "object to think with," not a dispenser of information. Like constructivists, he agreed that knowledge is actively constructed by learners rather than transmitted by a teacher. However, Papert believed that the construction of concrete artifacts or products "in the world" could support the construction of knowledge "in the head," while Piaget's constructivist theory focused on the construction of knowledge in one's head (Harel \& Papert, 1991). Papert's constructionism has recently gained increasing attention through the maker movement, which is discussed in the 21st Century section below.

\section{Instructional-Design Theory}

In the 1980s and 1990s, the awareness of and interest in instructional-design theories increased with Reigeluth's books on instructional-design theories and models. In the early 1980s, Reigeluth (1983) published the first volume, Instructional-Design Theories and Models: An Overview of their Current Status. The main purpose of the first volume was to raise awareness of instructional-design theories, which were largely overlooked in the shadows of ID process models.

Pointing out that instructional design is a prescriptive science, Reigeluth (1983) distinguished instructionaldesign theory from learning theory and instructional development in the first chapter of the first volume. Further, he emphasized that the focus of an instructional-design theory was on methods of facilitating learning rather than on processes of learning within a person's head. The first volume summarized some famous models and theories of instruction, including Merrill's Component Display Theory (CDT), Reigeluth's Elaboration Theory, and Keller's Motivational Design Model.

Reigeluth's (1999a) second volume, Instructional-Design Theories and Models: A New Paradigm of Instructional Theory, was published in 1999. In the first chapter, Reigeluth (1999b) defined an instructionaldesign theory as "a theory that offers explicit guidance on how to better help people learn and develop" (p. 5) and described characteristics and components of instructional-design theories in more detail. Emphasizing the 
need for a new paradigm of instructional-design theory, the second volume introduced various instructionaldesign theories and models that provided customized and learner-centered learning experiences, including Schank's Learning by Doing, Bransford's Flexibly Adaptive Instructional Designs, and Jonassen's Constructivist Learning Environments (CLE).

Reigeluth's work on instructional-design theory has made several contributions to the instructional design and technology field. First, he increased awareness of instructional-design theory by defining it and distinguishing it from learning theory and instructional development. Second, he encouraged and facilitated the development of instructional-design theory by specifying the components of instructional-design theories, providing a number of examples, and offering guidance for the theory-development process (Reigeluth, 1983, 1999a). Third, he introduced researchers, practitioners, and graduate students to a wide variety of instructional-design theories. Finally, he made a significant impact on the paradigm shift from teacher-centered to learner-centered education by emphasizing the need for this new paradigm of instructional-design theory and demonstrating many different ways to provide customized and learner-centered learning experiences (Reigeluth, 1999).

\section{1st Century}

\section{Social Media}

Today, there are a number of social media sites. Some popular social media, including Facebook, YouTube, and Twitter, were launched in the 2000s (Boyd \& Ellison, 2008). Social media refer to Web 2.0 technologies characterized by openness, user participation, user-created content, knowledge sharing, and social interaction (Alexander, 2006; Bingham, \& Conner, 2010; Brown \& Adler, 2008; Dao, 2015; Downes, 2005; Richardson, 2009; Thompson, 2007). While Web 1.0 was read-only, Web 2.0 is read/write and allows users to become active participants and content creators. They not only find information on the Internet, but they also create and publish content online and network with other people from all over the world.

Web 2.0 has "blurred the line between producers and consumers of content and has shifted attention from access to information toward access to other people" (Brown \& Adler, 2008, p. 18). According to a recent Pew Research Center survey, YouTube (73\%) and Facebook (69\%) are the most widely used social media sites among adults in the U.S. There are substantial age-related differences in the use of social media platforms. Snapchat and Instagram are the most popular apps among those ages 18 to 24 (Perrin \& Anderson, 2019).

Social media has the potential to create learner-centered learning environments by empowering learners to become knowledge creators and producers and providing opportunities for interaction and collaboration (Downes, 2005; Gikas \& Grant, 2013; Greenhow, 2011; Richardson, 2009). The use of social media in education is increasing but still limited and restricted (Manca \& Ranieri, 2016). Moran, Seaman, and Tinti-Kane (2011) found that over $90 \%$ of higher education faculty were using social media in their courses. However, the use of social media was limited primarily to online videos. Research studies show that some educators are hesitant to integrate social media into their teaching practices (Manca \& Ranieri, 2016; Zachos, Paraskevopoulou-Kollia, \& Anagnostopoulos, 2018). 


\section{Online and Blended Learning}

Online learning is one of the fastest growing areas in the ID field. Over the last decade, it has become popular because of its potential to make learning more accessible and flexible. In the fall of 2008, over 4.6 million students - over one quarter of U.S. higher education students - were taking at least one online course (Allen \& Seaman, 2010). In the corporate world, about 33\% of training was delivered electronically in 2007 (Paradise, 2008). Although the adoption of online learning in K-12 settings was slower compared to other settings, online learning in K-12 schools is increasing rapidly. The surveys commissioned by the Sloan Consortium (now known as the Online Learning Consortium) reported that 700,000 K-12 public school students took online courses in 2007-2008 (Picciano \& Seaman, 2007, 2008). The Florida Virtual School, the largest state virtual school, had more than 150,000 course enrollments in 2008-2009 (Watson, Gemin, Ryan \& Wicks, 2009). In 2017-18, nearly 300,000 students were enrolled in 501 full-time virtual schools (Molnar, 2019). Recently, the COVID-19 pandemic has forced K-12 schools and universities to move to online learning. The biggest online learning experiment in history began in the spring of 2020 when $90 \%$ of schools worldwide closed (UNESCO, 2020).

Another major trend in the 2000s is the emergence of blended or hybrid learning that combines online and faceto-face instruction (Allen \& Seaman, 2003; Graham, 2005). In 2003, the American Society for Training and Development identified blended learning as one of the top ten trends to emerge in the knowledge delivery industry (Rooney, 2003). Blended learning has the potential to empower learners by offering them choice and flexibility about when and where they can participate in the online portion of their course (Owston, 2017). Graham, Allen, and Ure (2005) found that blended learning was used mainly for three reasons: (1) improved pedagogy, (2) increased access and flexibility, and (3) increased cost-effectiveness.

\section{Mobile Learning}

As mobile technologies and devices advance, mobile learning, which is often called m-learning, is rapidly developing. Crompton (2013) defined m-learning as "learning across multiple contexts, through social and content interactions, using personal electronic devices." Today mobile phones have the same capabilities as microcomputers at a small fraction of the size. The portability, mobility, and ubiquity of mobile devices significantly reduce the dependence on fixed locations for learning and work, and they enable students to "learn the right thing at the right time at the right place" (Peng, Su, Chou, \& Tsai, 2009, p. 175). Mobile devices also have the potential to provide learner-centered learning experiences that are situated, authentic, and personalized (Traxler, 2011).

\section{The Open Educational Resource (OER) Movement}

Since the early 2000s, the OER movement has been growing. The term OER was coined at the Forum on the Impact of Open Courseware for Higher Education in Developing Countries in 2002 (UNESCO, 2002). The OER movement has its roots in earlier work around learning objects (Weller, 2014). It is generally agreed that OER are "teaching, learning, and research resources that reside in the public domain or have been released 
under an intellectual property license that permits their free use and repurposing by others" (William and Flora Hewlett Foundation, 2017). The OER Evidence Report 2013-2014 showed that although awareness of OER and Creative Commons was growing, general knowledge of well-established OER repositories was low. It appeared that $79.5 \%$ of educators and $74.9 \%$ of informal learners were using OER to get new ideas and learning experience. Videos were the most common type of OER used, and OER repositories were relatively unknown and unused compared with the three major resource sites of YouTube, Khan Academy, and TED (de los Arcos, Farrow, Perryman, Pitt \& Weller, 2014).

\section{Massive Open Online Courses (MOOCs)}

With the Open Educational Resource (OER) and OpenCourseWare (OCW) movements, MOOCs have rapidly grown since their inception a little over a decade ago. In 2001, MIT announced that it was making its entire curriculum of courses available in a free and open format. Several large-scale MOOC providers, such as Coursera, Udacity, and edX, were founded in 2012, which is called "the year of the MOOC" (Matkin, 2013). In 2015, MOOCs and Open Education Around the World edited by Bonk, Lee, Reeves, and Reynolds (2015) provided a comprehensive account of the range of MOOC initiatives and open education projects around the world. The number of available MOOCs has grown dramatically in the last few years. In 2018, 20 million new learners signed up for at least one MOOC, and over 900 universities around the world announced or launched 11,400 MOOCs by the end of 2018 (Shah, 2019).

MOOCs provide flexible learning opportunities to learners around the world for free or at low cost (Kaplan \& Haenlein, 2016; Porter, 2017). However, they have been criticized for low levels of learner engagement, high dropout rates, and low completion rates (Hone \& El Said, 2016; Jordan, 2014; Xing, Chen, Stein, \& Marcinkowski, 2016). Researchers report that the majority of MOOCs present a considerable amount of content mainly via video lecture formats and often fail to help leaners remain focused on learning content (Chang \& Wei, 2016; Klemke, Eradze, \& Antonaci, 2018). How to better engage and motivate learners in online environments with a large number of participants appears to be a key challenge for MOOCs.

\section{Virtual Reality (VR) and Augmented Reality (AR)}

The use of VR and AR in instructional environments is becoming increasingly popular in recent years. VR and AR are not really new technologies though. The term "virtual reality" was coined by Jaron Lanier in the 1980s (Fuchs, Moreau, \& Guitton, 2011), and the term "augmented reality" was coined by Thomas Caudell and David Mizell in 1990 (Elmqaddem, 2019). VR and AR have been explored as tools for education and training for the last few decades. Today, VR and AR are hot topics at conferences in the instructional design and technology field. Many researchers are exploring the educational applications of these technologies. Despite the enthusiasm for the technologies and research efforts on them, VR and AR have not been widely adopted in educational settings due to several constraints, including accessibility (Elmqaddem, 2019). Efforts are being made to make these technologies more accessible and affordable. Google was the pioneer in offering inexpensive VR platforms and headsets that started with Google Cardboard in 2014. Other companies have also developed more 
advanced versions of the Cardboard. Researchers note the need for theoretical guidelines or instructional principles that could assist teachers and instructors in integrating these technologies into learning environments effectively (Curcio, Dipace, \& Norlund, 2016).

\section{Digital Game-Based Learning (DGBL) and Gamification}

DGBL has been proposed as one of the ways to meet the needs today's learners who are "accustomed to the twitch-speed, multitasking, random-access, graphics-first, active, connected, fun, fantasy, and quick payoff world of their video games, MTV, and Internet” (Prensky, 2007, p. 64). In the 2000s, game researchers designed and developed many educational games or game-based learning environments in an attempt to help students develop important 21st century skills. For example, River City was designed to help middle school students learn scientific inquiry and 21st-century skills. Crystal Island: Lost Investigation, a science mystery game, was developed to help middle school students learn microbiology concepts and develop literacy skills.

Although these games have not been widely used in schools, they became representative examples of good games that incorporate good learning principles (Gee, 2005). The national survey conducted by the Joan Ganz Cooney Center reported that most game-using teachers were using shorter-form genres, such as drill-andpractice, trivia, and puzzle games (Takeuchi \& Vaala, 2014). Consequently, many teachers still do not fully understand the educational potential of digital games (Gaudelli \& Taylor, 2011; Schrader, Zheng \& Young, 2006).

Over the past decade, the interest in using gamification for learning has dramatically increased in this field. Gamification refers to the process of using game elements in non-game contexts to motivate and engage people, change behaviors, and solve real-world problems (Deterding, Dixon, Khaled, \& Nacke, 2011; Kapp, 2012; Zichermann, 2010). It has been applied in many other fields, including business, training, marketing, fitness, software engineering, and healthcare. Researchers such as Kapp (2012) and Simões, Redondo, and Vilas (2013) argue that gamification is crucial for the development of educational technology, since many elements of gamification are based on research in educational psychology and proven techniques that educators have relied on for years.

\section{The Maker Movement}

The maker culture has engaged people in the creative production of artifacts in their daily lives and encouraged them to share their products and processes with others through physical and digital forums (Halverson \& Sheridan, 2014). Dale Dougherty (2012) founded Make magazine, which was first released in January 2005. A year after the magazine, Maker Faire, an event created by Make magazine to celebrate innovative and creative projects, started in the Bay Area in 2006. Since the first Maker Faire held in San Mateo, California, Maker Faires and mini-Maker Faires have been held in different cities around North America, including Austin, Detroit, Michigan, and New York City. Mark Hatch (2014), CEO and cofounder of TechShop, proposed a "Maker Movement Manifesto" that describes maker's activities and mindsets and highlights the importance of 
construction of physical objects as a feature of the maker movement. The maker movement has led to an explosion of makerspaces around the United States across different learning environments, including museums, libraries, K-12 schools, afterschool clubs, community colleges, universities, and independent nonprofit and forprofit organizations.

\section{New ID Process Models}

Practitioners and researchers in the ID field have expressed concerns about traditional ID models developed in the 20th century. Critiques argued that traditional ID models were too linear, too slow, and inflexible (e.g., Zemke \& Rossett, 2002). In response to these criticisms, new ID models have been developed. For example, Tripp and Bichelmeyer (1990) proposed rapid prototyping, characterized by the "parallel processes of design and research, or construction and utilization," to reduce the time and cost of an ID project, while increasing flexibility and effectiveness (p. 37). As a non-linear, iterative approach, rapid prototyping produces the prototype of a part of the instruction and allows the client to see what the completed instruction will look like early in the process (Piskurich, 2015).

David Merrill (2002a) developed the pebble-in-the-pond model that facilitates the development of problemcentered instruction based on the first principles of instruction. Gibbons and Rogers (2009) proposed a layered approach to instructional design, which consists of seven design layers, including content layer, strategy layer, message layer, control layer, representation layer, media-logic layer, and data management layer. Recently, Reigeluth and An (2021) developed a new ID model called the Holistic 4D Model, which takes a holistic approach to instructional design. It stands in contrast to the fragmented approach that begins with an exhaustive analysis process. Rather than beginning the design process by breaking the content into small pieces and designing instruction for each of the pieces, the Holistic 4D Model begins the design process by creating a fuzzy vision or top-level design and proceeds to work out progressively more details for each part of it in two more cycles (mid-level and lower-level design).

\section{Instructional-Design Theory}

New instructional methods have been continually developed in response to different needs in educational and training environments and advances in information technology, learning science, brain science, and other relevant fields. However, as Reigeluth and Carr-Chellman (2009) pointed out, different instructional theorists and researchers have used the same term to refer to different things and different terms to refer to the same things working in relative isolation from each other. In order to build a common knowledge base about instruction with a consistent terminology, Reigeluth and Carr-Chellman (2009) published Instructional-Design Theories and Models: Building a Common Knowledge Base.

David Merrill (2002b, 2007, 2009) identified five prescriptive design principles for problem-centered instruction, which are called "first principles of instruction." The five principles included problem-centeredness, activation, demonstration (show me), application (let me), and integration. More recently, Reigeluth, Beatty, and 
Myers (2017) published Instructional-Design Theories and Models: The Learner-Centered Paradigm of Education. As its subtitle indicates, the fourth volume provides a comprehensive set of guidelines for the learner-centered paradigm of education and training, including for competency-based education, task-centered instruction, personalized instruction, changed roles for teachers and students, and changed curriculum.

\section{Conclusion}

The history of instructional media during the 20th century shows a recurrent pattern of enthusiasm and little effects on actual practices. As each new medium entered the world, there was a great deal of initial interest and enthusiasm about its anticipated impact on instructional practices. However, interest and enthusiasm eventually faded, and the medium had a minimal impact on instructional practices due to various factors, such as poor instructional quality, the costs associated with purchasing and maintaining the media and equipment, teacher resistance to change, lack of guidelines for integrating new media into instructional practices, and systemic barriers such as organizational structures (Reigeluth \& Karnopp, 2013; Reiser, 2018). With the OER movement, today's teachers have access to a variety of instructional media that are free and easy-to-use, but the issue of teacher resistance to change still exists. History teaches us that teacher resistance to change should be addressed first in order to facilitate teacher adoption and integration of instructional media and technology. Teachers should be able to see the value of the technology, feel comfortable and confident using it with their students, and experience positive effects of technology integration.

Learning theories and instructional-design theories have evolved in response to the new needs of society and people. In addition, computers and digital technologies in the 21 st century have had a significant impact on the ways we communicate and learn. However, ID models and practices do not show much change. Although researchers in the field have developed new ID models (e.g., Merrill, 2002a; Tripp \& Bichelmeyer, 1990), the ADDIE and similar models that were created in the 1960s and 1970s still remain popular and prevalent in ID practices (Reiser, 2018). Contemporary researchers emphasize the need to move from a fragmented to holistic approach to instruction and instructional design (e.g., Reigeluth \& An, 2021; Spector, 1995; Spector \& Anderson, 2000; van Merriënboer, 2007).

The history of the field in the 21 st century reveals that our field has been technology-centered over the last two decades. Bodily, Leary, and West (2019) examined research trends in the field of instructional design and technology through an analysis of the literature published in the Scopus database between 2007 and 2017. Their analysis showed that the scholarship in our field is very technology-centric with a large focus on hard, computer-based technologies and that there is a lack of recent scholarship on learning and instructional theories and design frameworks. As the researchers suggested, our field could benefit from more efforts on theory and design frameworks.

\section{Acknowledgements}

I greatly appreciate the thoughtful comments of Dr. Charles M. Reigeluth on an earlier version of this paper. 


\section{References}

Alexander, B. (2006). Web 2.0: A new wave of innovation for teaching and learning? EDUCAUSE Review, $41(2), 32-44$.

Allen, I. E., \& Seaman, J. (2003). Sizing the opportunity: The quality and extent of online education in the $\begin{array}{lllll}\text { United States, } & 2002 \text { and } & \text { Retrieved }\end{array}$ http://sloanconsortium.org/publications/survey/sizing_the_opportunity2003

Allen, I. E., \& Seaman, J. (2010). Learning on demand: Online education in the United States, 2009. Retrieved from http://www.sloanc.org/publications/survey/pdf/learningondemand.pdf

Arenson, K. (1998a). N.Y.U sees profits in virtual classes. The New York Times. Retrieved from http://www.nytimes.com/1998/10/07/nyregion/nyu-sees-profi ts-invirtual-classes.htm

Arenson, K. (1998b). More colleges plunging into uncharted waters of on-line courses. The New York Times. Retrieved from https://www.nytimes.com/1998/11/02/us/more-collegesplunging-into-uncharted-waters-of-on-line-courses.html

Becker, H. J. (1998). Running to catch a moving train: Schools and information technologies. Theory into Practice, 37(1), 20-30.

Bloom, B. S., Engelhart, M. D., Furst, E. J., Hill, W. H., \& Krathwohl, D. R. (1956). Taxonomy of educational objectives: The classification of educational goals. Handbook 1: Cognitive Domain. New York: David McKay.

Bingham, T., \& Conner, M. (2010). The new social learning: A guide to transforming organizations through social media. San Francisco, CA: Berrett-Koehler Publishers.

Bodily, R., Leary, H., \& West, R. E. (2019). Research trends in instructional design and technology journals. British Journal of Educational Technology, 50(1), 64-79.

Bonk, C. J., Lee, M. M., Reeves, T. C., \& Reynolds, T. H. (2015). MOOCs and open education around the world. New York: Routledge.

Boyd, D., \& Ellison, N. (2008). Social network sites: Definition, history, and scholarship. Journal of Computer Mediated Communication, 13(1), 210-230.

Brown, J. S., \& Adler, R. P. (2008). Minds on fire: Open education, the long tail, and learning 2.0. EDUCAUSE Review, 43(1), 17-32.

Bruner, J. (1966). Toward a Theory of Instruction. Cambridge, MA: Harvard University Press.

Center for Social Organization of Schools (1983). School uses of. Microcomputers: Reports from a national survey (Issue no. 1). Baltimore, MD: Johns Hopkins University, Center for Social Organization of Schools.

Chang, J. W., \& Wei, H. Y. (2016). Exploring engaging gamification mechanics in massive online open courses. Educational Technology \& Society, 19(2), 177-203.

Clark, R.E. (1983). Reconsidering research on learning from media. Review of Educational Research, 53(4), 445-459.

Collins, A., Brown, J.S., \& Newman, S.E. (1989). Cognitive apprenticeship: Teaching the crafts of reading, writing, and mathematics. In L. B. Resnick (Ed.) Knowing, learning, and instruction: Essays in honor of Robert Glaser (pp. 453-494). Hillsdale, NJ: Lawrence Erlbaum Associates. 
Crompton, H. (2013). A historical overview of mobile learning: Toward learner-centered education. In Z. L. Berge, L. Y. Muilenburg, \& J. Crompton (Eds.), Handbook of mobile learning (pp. 3-14). Florence, KY: Routledge.

Cuban, L. (1986). Teachers and machines: The classroom use of technology since 1920. New York: Teachers College Press.

Curcio, I. D. D., Dipace, A., \& Norlund, A. (2016). Virtual realities and education. Research on Education and Media, 8(2), 60-68.

Dao, D. V. (2015). Social Media Classification Scheme in Online Teaching and Learning Activities: A Consideration for Educators. International Journal of Education and Social Science, 2(4), 85-94.

de los Arcos, B., Farrow, R., Perryman, L.-A., Pitt, R., \& Weller, M. (2014). OER Evidence Report 2013-2014. OER Research Hub. Retrieved from http://oerresearchhub.org/about-2/reports/

Deterding, S., Dixon, D., Khaled, R., \& Nacke, L. (2011). From game design elements to gamefulness: Defining "gamification." Proceedings of the 15th International Academic MindTrek Conference (pp. 9-15). Tampere, Finland.

Dick, W. (1987). A history of instructional design and its impact on educational psychology. In J. Glover \& R. Roning (Eds.), Historical foundations of educational psychology. New York: Plenum.

Dick, W., \& Carey, L. (1978). The systematic design of instruction (1st ed.). Glenview, IL: Scott, Foresman.

Dillon, A., \& Gabbard, R. (1998). Hypermedia as an educational technology: A review of the quantitative research literature on learner comprehension, control, and style. Review of Educational Research, 68(3), 322-349.

Dougherty, D. (2012). The maker movement. Innovations, 7(3), 11-14.

Downes, S. (2005). E-learning 2.0. eLearn Magazine. Retrieved from http://www.elearnmag.org/

Duffy, T. M., \& Cunningham, D. J. (1996). Constructivism: Implications for the design and delivery of instruction. In D. Jonassen (Ed.), Handbook of research for educational communications and technology. New York: Macmillan.

Edgar, D. W. (2012). Learning theories and historical events affecting instructional design in education: Recitation literacy toward extraction literacy practices. SAGE Open, 2, 1-9.

Elmqaddem, N. (2019). Augmented reality and virtual reality in education: Myth or reality? International Journal of Emerging Technologies in Learning, 14(3), 234-242.

Ertmer, P. A., \& Newby, T. J. (2013). Behaviorism, cognitivism, constructivism: Comparing critical features from an instructional design perspective. Performance Improvement Quarterly, 26(2), 43-71.

Finn, J. D. (1972). The emerging technology of education. In R. J. McBeath (Ed.), Extending education through technology: Selected writings by James D. Finn. Washington, DC: Association for Educational Communications and Technology.

Fuchs, P., Moreau, G., \& Guitton, P. (2011). Virtual reality: Concepts and technologies. CRC Press.

Gagné, R. M. (1965). The conditions of learning (1st Ed.). New York: Holt, Rinehart \& Winston.

Gagné, R. M. (1985). The Conditions of Learning (4th Ed.). New York: Holt, Rinehart \& Winston.

Gagné, R. M., \& Briggs, L. J. (1974). Principles of instructional design (1st ed.). New York: Holt, Rinehart, and Winston.

Gaudelli, W., \& Talyor, A. (2011). Modding the global classroom? Serious video games and teacher reflection. 
Contemporary Issues in Technology \& Teacher Education, 11(1), 70-91.

Gee, J. P. (2005). Good video games and good learning. Phi Kappa Phi Forum, 85(2), 33-37.

Gerlach, V. S., \& Ely, D. P. (1971). Teaching and media: A systematic approach (1st ed.). Englewood Cliffs, NJ: Prentice-Hall.

Gery, G. J. (1991). Electronic performance support systems: How and why to remake the workplace through the strategic application of technology. Boston, MA: Weingarten Publications.

Gibbons, A. S., \& Rogers, P. C. (2009). The architecture of instructional theory. In C. Reigeluth and A. CarrChellman (Eds.), Instructional-design theories and models, Volume III (pp. 305-326). New York: Routledge.

Gikas, J., \& Grant, M. M. (2013). Mobile computing devices in higher education: Student perspectives on learning with cellphones, smartphones \& social media, Internet and Higher Education, 19, 18-26.

Glaser, R. (1962). Psychology and instructional technology. In R. Glaser (Ed.), Training research and education. Pittsburgh: University of Pittsburgh Press.

Graham, C. R. (2005). Blended learning systems: Definition, current trends, and future directions. In C. J. Bonk \& C. R. Graham (Eds.), Handbook of blended learning: Global perspectives, local designs (pp. 3-21). San Francisco, CA: Pfeiffer.

Graham, C. R., Allen, S., \& Ure, D. (2005). Benefits and challenges of blended learning environments. In M. Khosrow-Pour (Ed.), Encyclopedia of information science and technology (pp. 253-259). Hershey, PA: Idea Group.

Greenhow, C. (2011). Youth, learning, and social media. Journal of Educational Computing Research, 45(2), 139-146.

Halverson, E. R., \& Sheridan, K. M. (2014). The maker movement in education. Harvard Education Review, 84(4), 495-504.

Harel, I., \& Papert, S. (1991). Software design as learning environment. In I. Harel \& S. Papert (Eds.), Children designers: Interdisciplinary constructions for learning and knowing mathematics in a computer-rich school (pp. 41-85). Noorwood: Ablex.

Hatch, M. (2014). The maker movement manifesto. Retrieved from https://www.boerneneshovedstad.dk/media/1332/maker-movement-manifesto-sample-chapter.pdf

Heaviside, S., Riggins, T., \& Farris, E. (1997). Advanced telecommunications in U.S. public elementary and secondary schools, fall 1996 (NCES 97-944). U.S. Department of Education. Washington, DC: National Center for Education Statistics.

Heinich, R., Molenda, M., Russell, J.D., \& Smaldino (1999). Instructional media and technologies for learning (6th ed.). Upper Saddle River, NJ: Prentice Hall.

Hone, K S, \& El Said G. R. (2016). Exploring the factors affecting MOOC retention: A survey study. Computers \& Education, 98, 157-168.

Johnson, T. E., Xin, X., Mackal, M., \& Reiser, R. A. (2012). Textbooks used in graduate programs in instructional design and technology: Comparisons across time and countries. Educational Technology, 52(4), 25-32.

Jonassen, D. H. (1997). Instructional design model for well-structured and ill-structured problem-solving learning outcomes. Educational Technology Research and Development 45(1), 65-95. 
Jonassen, D. H. (1999). Designing constructivist learning environments. In C. M. Reigeluth (Ed.), Instructional design theories and models: A new paradigm of instructional theory (Vol. II, pp. 215-239). Mahwah, NJ: Lawrence Erlbaum Associates.

Jordan, K. (2014). Initial trends in enrolment and completion of massive open online courses Massive Open Online Courses. The International Review of Research in Open and Distributed Learning, 15, 133-160.

Kaplan, A. M., \& Haenlein, M. (2016). Higher education and the digital revolution: About MOOCs, SPOCs, social media, and the Cookie Monster. Business Horizons, 59(4), 441-450. https://doi.org/10.1016/j.bushor.2016.03.008

Kapp, K. M. (2012). The gamification of learning and instruction: game-based methods and strategies for training and education. San Francisco, CA: Pfeiffer.

Kemp, J. E. (1971). Instructional design: A plan for unit and course development. Belmont, CA: Fearon.

Kentnor, H. E. (2015). Distance education and the evolution of online learning in the United States. Curriculum and Teaching Dialogue, $17(1 \& 2), 21-34$.

Klemke, R., Eradze, M., \& Antonaci, A. (2018, February). The flipped MOOC: Using gamification and learning analytics in MOOC design - A conceptual approach. Educational Sciences, 8(25), doi:10.3390/educsci8010025

Koszalka, T., Russ-Eft, D., \& Reiser, R. (2013). Instructional design competencies: The standards (4th Ed). Charlotte, NC: Information Age Publishing.

Kozma, R.B. (1994). Will media influence learning? Reframing the debate. Journal of Educational Technology Research and Development, 42(2), 7-19.

Lewis, B. N., \& Pask, G. (1965). The theory and practice of adaptive teaching systems. In R. Glaser (Ed.), Teaching machines and programmed learning II: Data and directions. Washington, DC: National Education Association.

Liao, Y. C. (1999). Effects of hypermedia on students' achievement: A meta-analysis. Journal of Educational Multimedia and Hypermedia, 8(3), 255-277.

Mager, R. F. (1962). Preparing objectives for programmed instruction. Belmont, CA: Fearon.

Manca, S., \& Ranieri, M. (2016). Facebook and the others: Potentials and obstacles of social media for teaching in higher education. Computers \& Education, 95, 216-230.

Matkin, G.W. (2013). Massive open online courses: Looking ahead by looking back. Continuing Higher Education Review, 77, 49-56.

McCluskey, F. D. (1981). DVI, DAVI, AECT: A long view. In J.W. Brown \& S. N. Brown (Eds.), Educational media yearbook: 1981. Littleton, CO: Libraries Unlimited.

McLeod, S. (2018). Jean Piaget's theory of cognitive development. Simply Psychology. Retrieved from https://www.simplypsychology.org/piaget.html

Merrill, M. D. (2002a). A pebble-in-the-pond model for instructional design. Performance Improvement, 41(7), 39-44.

Merrill, M. D. (2002b). First principles of instruction. Educational Technology Research and Development, 50(3), 43-59.

Merrill, M. D. (2007). First principles of instruction: A synthesis. In R. A. Reiser \& J. V. Dempsey (Eds.), Trends and issues in instructional design and technology (2nd ed., pp. 62-71). Upper Saddle River, NJ: 
Merrill/Prentice-Hall.

Merrill, M. D. (2009). First principles of instruction. In C. M. Reigeluth \& A. A. Carr-Chellman (Eds.), Instructional-design theories and models: Building a common knowledge base (Vol. III, pp. 41-56). New York: Routledge.

Miller, R. B. (1962). Analysis and specification of behavior for training. In R. Glaser (Ed.), Training research and education. Pittsburgh: University of Pittsburgh Press.

Molenda, M. (2008). Historical foundations. In J. M. Spector, M. D. Merrill, J. V. Merriënboer, \& M. P. Driscoll (Eds.), Handbook of research on educational communications and technology ( ${ }^{\text {rd }}$ ed.) (pp. 320). New York: Taylor \& Francis Group.

Molnar, A. (2019). Virtual schools in the U.S. 2019: Executive summary. Retrieved from https://nepc.colorado.edu/sites/default/files/publications/RB\%20Exec\%20Summary\%20with\%20blurb.p df

Moran, M., Seaman, J., \&, Tinti-Kane, H. (2011). Teaching, learning, and sharing: How today's higher education faculty use. Social media. Pearson Learning Solutions and Babson Survey Research Group.

Office of Technology Assessment. (1995). Teachers \& technology: Making the connection. Washington, DC: Office of Technology Assessment.

Owston, R. (2017). Empowering learners through blended learning. International Journal on E-Learning, 17(1), 65-83.

Pagliaro, L. A. (1983). The history and development of CAI: 1926-1981, an overview. Alberta Journal of Educational Research, 29(1), 75-84.

Papert, S. (1993a). Mindstorms: Children, computers, and powerful ideas (2nd ed.). New York: Basic Books.

Papert, S. (1993b). The children's machine: Rethinking schools in the age of the computer. New York: Basic. Books.

Paradise, A. (2008). 2007 State of the industry report. Alexandria, VA: American Society of Training and Development.

Peng, H., Su, Y. J., Chou, C., \& Tsai, C. C. (2009). Ubiquitous knowledge construction: mobile learning redefined and a conceptual framework. Innovations in Education and Teaching International, 46(2), 171183. doi:10.1080/14703290902843828

Perrin, A., \& Anderson, M. (2019). Share of U.S. adults using social media, including Facebook, is mostly unchanged since 2018. Retrieved from https:/www.pewresearch.org/fact-tank/2019/04/10/share-of-u-sadults-using-social-media-including-

facebook-is-mostly-unchanged-since-2018/

Picciano, A. G., \& Seaman, J. (2007). K-12 online learning: A survey of U.S. school district administrators. Retrieved from http://www.sloan c.org/publications/survey/K-12_06.asp

Picciano, A. G., \& Seaman, J. (2008). Staying the course: Online education in the United States. Retrieved from http://www.sloanc.org/publications/survey/pdf/staying_the_course.pdf

Piskurich, G. M. (2015). Rapid instructional design: Learning ID fast and right (3rd ed.). Hoboken, NJ: John Wiley \& Sons, Inc.

Porter, S. (2017). To MOOC or not to MOOC: How can online learning help to build the future of higher education? Oxford, UK: Chandos Publishing. 
Prensky, M. (2007). Digital game-based learning. St. Paul, MN: Paragon House.Redfield, D. D., \& Dick, W. (1984). An alumni-practitioner review of doctoral competencies in instructional systems. Journal of Instructional Development, 7(1), 10-13.

Reigeluth, C. M. (1983). Instructional-design theories and models: An overview of their current status. Hillsdale, NJ: Lawrence Erlbaum Associates.

Reigeluth, C. M. (1999a). Instructional-design theories and models: A new paradigm of instructional theory (Vol. II). Mahwah, N.J.: Lawrence Erlbaum Associates.

Reigeluth, C. M. (1999b). What is instructional-design theory and how is it changing? In C. M. Reigeluth (Ed.), Instructional-design theories and models: A new paradigm of instructional theory (Vol. II, pp. 5-29). Mahwah, NJ: Lawrence Erlbaum Associates.

Reigeluth, C. M., \& An, Y. (2021). Merging the instructional design process with learner-centered theory: The holistic 4D model. Routledge.

Reigeluth, C. M., Beatty, B. J., \& Myers, R. D. (2017). Instructional-Design Theories and Models: The Learner-Centered Paradigm of Education (Vol. IV). New York: Routledge.

Reigeluth, C. M., \& Carr-Chellman, A. A. (Eds.). (2009). Instructional-design theories and models: Building a common knowledge base (Vol. III). New York: Routledge.

Reigeluth, C. M., \& Karnopp, J. R. (2013). Reinventing schools: It's time to break the mold. Lanham, MD: Rowman \& Littlefield Education.

Reigeluth, C. M., \& Merrill, M. D. (1978). A knowledge base for improving our methods of instruction. Educational Psychologist, 13, 57-70.

Reigeluth, C. M., \&. Merrill, M. D. (1979). Classes of instructional variables. Educational Technology, 19(3), $5-24$.

Reiser, R. A. (2001a). A history of instructional design and technology: Part. I: A history of instructional media. Educational Technology Research and Development, 49(1), 53-63.

Reiser, R. A. (2001b). A history of instructional design and technology: Part. II: A history of instructional design. Educational Technology Research and Development, 49(2), 57-67.

Reiser, R. A. (2018). A history of instructional design and technology. In R.A. Reiser \& J.V. Dempsey (Eds.), Trends and Issues in Instructional Design and Technology (4th ed). New York, NY: Pearson Education.

Richardson, W. (2009). Blogs, wikis, podcasts, and other powerful web tools for classrooms (2nd ed.). Thousand Oaks, CA: Corwin Press.

Rooney, J. E. (2003). Blending learning opportunities to enhance educational programming and meetings. Association Management, 55(5), 26-32.

Saettler, P. (1968). A history of instructional technology. New York: McGraw-Hill.

Saettler, P. (1990). The evolution of American educational technology. Englewood, CO: Libraries Unlimited.

Savery, J.R., \& Duffy, T.M. (1995). Problem-based learning: An instructional model and its constructivist framework. In B. Wilson (Ed.), Constructivist learning environments: Case studies in instructional design (pp. 135-148). Englewood Cliffs, NJ: Educational Technology Publications.

Schank, R. (1994). What we learn when we learn by doing. Evanston, IL: Northwestern University Press.

Schrader, P. G., Zheng, D., \& Young, M. (2006). Teachers' perceptions of video games: MMOGs and the future of pre-service teacher education. Innovate: Journal of Online Education, 2(3), 1-10. 
Schwen, T. M., Kalman, H. K., Hara, N., \& Kisling, E. L. (1998). Potential knowledge management contributions to human performance technology research and practice. Educational Technology Research and Development, 46(4), 73-89.

Scriven, M. (1967). The methodology of evaluation. In Perspectives of Curriculum Evaluation (American Educational Research Association Monograph Series on Curriculum Evaluation, No. 1). Chicago: Rand McNally.

Shah, D. (2019, January 6). Year of MOOC-based degrees: A review of MOOC stats and trends in 2018. Class Central. Retrieved from https://www.class-central.com/report/moocs-stats-and-trends-2018

Simões, J., Redondo, R. D., \& Vilas, A. F. (2013). A social gamification framework for a K-6 learning platform. Computers in Human Behavior, 29(2), 345-353.

Skinner, B. F. (1938). The Behavior of organisms: An experimental analysis. New York: Appleton-Century.

Skinner, B. F. (1958). Teaching machines. Science, 128 (3330), 969-977.

Snelbecker, G. E. (1983). Is instructional theory alive and well? In C.M. Reigeluth (Ed.), Instructional design theories and models: An overview of their current status (pp. 437-472). Hillsdale, NJ: Lawrence Erlbaum.

Spector, J. M. (1995). Integrating and humanizing the process of automating instructional design. In R. D. Tennyson \& A. E. Barron (Eds.), Automating instructional design: computer-based development and delivery tools (pp. 523-546). Berlin: Springer-Verlag.

Spector, J. M., \& Anderson, T. M. (Eds.) (2000). Integrated and holistic perspectives on learning and instruction: Understanding complexity. Dordrecht: Kluwer.

Stolorow, L. M., \& Davis, D. (1965). Teaching machines and computer-assisted systems. In R. Glaser (Ed.), Teaching machines and programmed learning II: Data and directions. Washington, DC: National Education Association.

Sweller, J. (1988). Cognitive load during problem solving: Effects on learning. Cognitive Science, 12, 257-285. Takeuchi, L. M., \& Vaala, S. (2014). Level up learning: A national survey on teaching with digital games. $\quad$ Retrieved from http://www.joanganzcooneycenter.org/wpcontent/uploads/2014/10/jgcc_leveluplearning_final.pdf

Thompson, J. (2007). Is education 1.0 ready for web 2.0 students? Innovate, 3(4). Retrieved from https://nsuworks.nova.edu/innovate/vol3/iss4/5/

Thorndike, E. L. (1905). The elements of psychology. New York: A. G. Seiler.

Traxler, J. (2011). Introduction. In J. Traxler \& J. Wishart (Eds.), Making mobile learning work: Case studies of practice (pp. 4-12). Bristol, UK: ESCalate: HEA Subject Centre for Education.

Tripp, S., \& Bichelmeyer, B. (1990). Rapid prototyping: An alternative instructional design strategy.

Educational Technology Research and Development, 38(1), 31-44.

UNESCO. (2002). Forum on the impact of Open Courseware for higher education in developing countries: Final report. Paris: Author. Retrieved from http://unesdoc.unesco.org/images/0012/001285/128515e.pdf

UNESCO. (2020). Education: From disruption to recovery. Retrieved from https://en.unesco.org/covid19/educationresponse

van Merriënboer, J. J. G. (1997). Training complex cognitive skills: A four-component instructional design model for technical training. Englewood Cliffs, NJ: Educational Technology Publications. 
van Merriënboer, J. J. G. (2007). Alternate models of instructional design: Holistic design approaches and complex learning. In R. A. Reiser \& J. V. Dempsey (Eds.), Trends and issues in instructional design and technology (pp. 255-284). Upper Saddle River, New Jersey: Merrill/Prentice Hall.

Watson, J. B. (1913). Psychology as the behaviorist views it. Psychological Review, 20, 158-177.

Watson, J. F., Gemin, B., Ryan, J., \& Wicks, M. (2009). Keeping pace with K-12 online learning: A review of state-level policy and practice. Retrieved from http://www.kpk12.com/downloads/KeepingPace09fullreport.pdf

Weller, M. (2014). The battle for open how openness won and why it doesn't feel like victory. London: Ubiquity Press.

Weller, H., Repman, J., Lan, W., \& Rooze, G. (1995). Improving the effectiveness of learning through hypermedia-based instruction: the importance of learner characteristics. Computers in Human Behavior, $11(3-4), 451-465$.

William and Flora Hewlett Foundation. (2017). Open educational resources. Retrieved from http://www.hewlett.org/strategy/open-educational-resources

Woolfolk, A. (2010). Educational psychology (11 ${ }^{\text {th }}$ ed.). Upper Saddle River, NJ: Merrill.

Xing, W., Chen, X., Stein, J., \& Marcinkowski, M. (2016). Temporal predication of dropouts in MOOCs:

Reaching the low hanging fruit through stacking generalization. Computers in Human Behavior, 58, 119-129. https://doi.org/10.1016/j.chb.2015.12.007

Zemke, R., \& Rossett, A. (2002). A hard look at ISD. Training, 39(2), 26-34.

Zichermann, G. (2010). Fun is the future: Mastering gamification. Retrieved from http://www.youtube.com/watch? $=601 \mathrm{gNVeaE} 4 \mathrm{~g}$

Zachos, G., Paraskevopoulou-Kollia, E-A., \& Anagnostopoulos, I. (2018). Social media use in higher education: A review. Education Sciences, 8, 194, doi:10.3390/educsci8040194

\section{Author Information}

\section{Yunjo An}

https://orcid.org/0000-0002-2763-1297

University of North Texas

United States

Contact e-mail: yunjo.an@unt.edu 